Romance Languages and Literatures 



\section{Romance Languages and Literatures}

College of Literature, Science, and the Arts

The University of Michigan: An Encyclopedic Survey 
Copyright @ 2015 by the Regents of the University of Michigan

The University of Michigan: An Encyclopedic Survey was first published beginning in 1942. For its 2017 Bicentennial, the University undertook the most significant updating of the

Encyclopedia since the original, focusing on academic units. Entries from all versions are compiled in the Bicentennial digital and print-on-demand edition. 


\section{Contents}

1. Romance Languages and Literatures (1942)

William A. McLaughlin, Joseph N. Lincoln, and

Camillo P. Merlino

2. Romance Languages and Literatures (1975) James C. O'Neill

3. Romance Languages and Literatures (2013)

Steven N. Dworkin 



\section{Romance Languages and Literatures (1942)}

\section{William A. McLaughlin, Joseph N. Lincoln, and Camillo P. Merlino}

THE study of Romance languages at the University was provided for in 1846 by the appointment of Louis Fasquelle to the professorship of modern languages, a chair that had been specifically listed in the organic act of 1837 as one for which provision should be made. His actual service did not begin, however, until May, 1847.

French was the first modern language taught in the University; it has been given continuously since the spring of 1847 . According to the Catalogue, a short course in Italian was introduced in the fall of 1848 and one in Spanish in the spring of 1849, but, when German was begun the next fall, Italian and Spanish were dropped, and neither was revived for about twenty years.

This early development of modern language instruction was in accord with a general recognition among Eastern colleges of the desirability of these studies. Longfellow had been appointed 
professor of modern languages at Bowdoin in 1829 and professor of modern languages and belles-lettres at Harvard in 1836. Nevertheless, few permanent chairs in the modern languages were established; most of the colleges offering such studies gave them only sporadically and unsystematically. The early appointment of Fasquelle to a professorship of modern languages - perhaps the first to be maintained in the Middle West - was evidence of the progressive spirit characteristic of the framers of the curriculum, although the claim made by the Board of Visitors in 1848 that "in this respect the University possesses superior privileges" no doubt indicated a limited point of view.

Throughout the period 1847-87 there was a professor of modern languages. A second full professorship was set up in the department in 1867, when Adam K. Spence, who had taught French continuously since the fall of 1859, as well as Greek (1858-67) and Latin (1860-63), was appointed Professor of the French Language and Literature. In the autumn of 1870, upon the resignations of Spence and of Edward P. Evans, Professor of Modern Languages, the Board of Regents found the time opportune for a change of policy. Henry S. Frieze, who was then Acting President, later described the situation in the following words:

In 1870 the resignation of the professors of German and French in the University of Michigan led the regents to adopt the plan of organizing the instruction in modern languages under one professor with assistant instructors; and they authorized the Acting President to engage someone competent to take charge of the department.

(Frieze, p.70.)

The professorship of the French language and literature was thereupon discontinued for the time, and an attempt was made to bring in foreign-born instructors to teach the elementary work in their native languages. Soon afterward two instructors in French and one in German were giving the elementary and intermediate work, and the department head was teaching the intermediate and advanced French and senior German, in addition to a class in Italian.

In 1887 the Regents granted a departmental petition 
requesting the formation of the Department of Romance Languages and Literatures and the Department of Germanic Languages and Literatures.

In 1889 special courses in French and German for engineering students were segregated. The Department of Engineering was made a separate unit in 1895, but until 1904 the French and Spanish credited toward graduation in engineering continued to be given in the Department of Romance Languages. In May of that year the Regents appointed William Henry Wait (Northwestern '79, Ph.D. Allegheny '88), who had conducted German classes for engineering students since 1901, Professor of Modern Languages in the Department of Engineering, and it was not until 1928 that the work in German and the Romance languages was transferred back to the College of Literature, Science, and the Arts. In 1931, by a vote of the faculty of the College of Engineering, foreign languages were eliminated as subjects required for graduation, and as a result the enrollment in Romance languages dropped from 2,571 (1930-31) to 2,201 (1931-32). As early as 1914, to provide for the special needs of students in science, Alfred O. Lee, then Assistant Professor of Modern Languages in the Department of Engineering, offered a course in the reading of French scientific works and current journals.

Aside from the changes in the method of providing language instruction for engineering students, the only major change in the structure of the Department of Romance Languages was the introduction in 1933 of the new form of administration by a committee acting with the chairman, similar to the reorganized government of the College of Literature, Science, and the Arts which went into effect in August of that year.

During the past hundred years the Romance language staff has been augmented to meet increases in enrollment, courses have been multiplied to satisfy the growing demand and a constantly developing interest, new fields of study have been opened up in response to various needs as these became apparent, and graduate work has been fostered and intensified. From its very modest beginnings the Department of Romance Languages and Literatures has expanded until at the present its staff numbers three professors, seven associate professors, seven 
assistant professors, thirteen instructors, and four teaching fellows. In 1940 it had an enrollment of 1,893 at the end of the second semester and offered forty courses - seven elementary, nine intermediate, and twenty-four advanced.

The old Museum was remodeled for the use of the department in 1928 and was designated the Romance Language Building.

\section{French}

Louis Fasquelle, 1847-62. - A course in French was announced for the first time in the Catalogue for 1846-47. This course was given in the last third of the sophomore year. Another term was added in the autumn of 1848 , the first term of the junior year. There was no indication of the content or character of these courses. However, in the Catalogue for 1852-53, under the heading of modern languages, was the following statement: "The course of instruction in this department occupies one daily recitation during six terms, or two years. One half of the time is devoted to the French language, the other half to the German." There followed a description of each term's work, with the titles of the textbooks used and of the literary works read.

Although in the Catalogue Fasquelle was designated as Professor of Modern Languages and Literature from 1854 onward, the instruction offered in French presented no change of consequence until 1858-59, when it was extended from one year to three semesters, beginning in the sophomore year and continuing through the junior year. In 1859-60 the program was again limited to two semesters, but Adam Knight Spence ('58, A.M. '61), formerly Instructor in Greek only, was made Instructor in Greek and French.

The professors at the University in its early days are reputed to have been rather picturesque characters, and not the least picturesque among them, apparently, was Louis Fasquelle, whose struggles with the intricacies of English pronunciation, accent, and emphasis, not to mention idiom, gave rise to many stories that ultimately became classic and of general application. He was born in 1808 near Calais, France. His education he 
received at the famous École Polytechnique in Paris. He studied also in Germany. Because of his participation in the revolutionary movement of 1830, he left France for England, where he taught French and married. In 1832 he came to the United States. "He bought a farm in Michigan and divided his time between farming and the teaching of French to private pupils until his appointment to the chair of Modern Languages..." (Hinsdale, p. 223). For this post he was well fitted, because of his training, travels, and teaching experience. Virtually a pioneer in the field, he published during the last decade of his life (1852-61) a comprehensive series of textbooks for the teaching of French which, widely used throughout the country, contributed not a little to the prestige of the University. As a professor he proved "peculiar but very learned and proficient." He was considered one of the University's "brightest ornaments and one of the most faithful, devoted and useful members of its Academic Faculty," and his death in October, 1862 , left a vacancy "not easily to be supplied" (R.P., 1837-64, p. 1033).

Edward P. Evans, 1862-70. - After serving for a year as an instructor Edward Payson Evans ('54) became head of the department as Professor of Modern Languages and Literature in October, 1863. It may be noted in passing that he was apparently the first University officer charged officially with keeping the records of the alumni.

Evidence of increased interest in the study of modern languages and literature, or of greater ambition on the part of the staff, may be seen in the announcement in the Catalogue for 1863-64 that the subjects taught in the department were: (1) the French and German languages, (2) French and German literature, and (3) the general principles of comparative philology.

In 1864 another year of French was added to the scientific curriculum, and when the Latin and scientific course was introduced in 1867, two and one-half semesters of French were included in it. At the same time, however, one-half of the recommended year of French in the classical course was made optional.

George S. Morris, 1870-79. - George Sylvester Morris 
(Dartmouth '61, Ph.D. hon. Michigan '81) was appointed to the professorship of modern languages and literature in 1870. In his first year he was assisted by Instructor Jules Frederick Billard (Hobart '58, A.M. ibid. '61, M.D. Howard Univ. '84) in French and by Augustus Maasberg in German. The next year Robert Harbison replaced Maasberg, and there were two younger men teaching French, Billard and Paul Rousseau Bellon de Pont, Instructor in French and Drawing, who had prepared in both arts and science at the Collège Rollin, Paris. The content and number of the courses in 1871-72 remained substantially the same, except that in all French classes French conversation and composition were included. Alfred Hennequin (A.M. hon. '73, Ph.D. Lenox Collegiate Inst. '82) became Instructor in French in 1872, succeeding Billard. In 1872-73 it was announced that the courses in French would thereafter be essentially changed, and the following year it was stated that the work would be "directed in general towards increased practical facility in speaking and writing." Candidates for admission to the classical course were advised to study French at least one year before entering the University, but for admission to the other courses French was required. Mention was made in the Calendar for 1874-75 of the "large facilities for the study of the Modern Languages with reference to the oral use of them, or to the reading of foreign treatises on Science."

Morris had had excellent preparation in philosophy and was eager to continue in that subject. For several years after 1877 he divided his time between Johns Hopkins and the University of Michigan, teaching at Baltimore from Christmas vacation until the second semester. He attempted to resign from the University of Michigan in June, 1879, but consented to remain one more semester while his successor, Edward Lorraine Walter ('68, Ph.D. Leipzig '77), completed certain studies abroad. Walter had been an assistant professor in the Department of Latin since 1868 and acting head of that department for two years. In 1881-82 Morris returned to Ann Arbor to teach his favorite subject, philosophy. From 1870 until his death in 1889, he served on the faculty during at least a part of every academic year except 1880-81, and his thought had a profound effect upon the scholarly life and reputation of the University. 
Edward L. Walter, 1879-98. - In July, 1887, Edward L. Walter and another member of the department, Calvin Thomas ('74, A.M. '77, LL.D. '04), presented to the Regents a memorial in which they urged that the Department of Modern Languages be divided, and that there be established "in lieu of the present single professorship of Modern Languages, two professorships, one of Romance Languages and Literatures and one of Germanic Languages and Literatures." Figures were presented to show that the Department of Modern Languages was then the largest in the University, and reference was made to the growth of modern philology and to the practice in German universities and in some of the universities of this country, such as Johns Hopkins, Bryn Mawr, Cornell, and Indiana. The memorial read in part as follows:

So far as our own University is concerned, a considerable extension in the scope of its instruction is desirable. There should be continuous instruction in both Italian and Spanish. Opportunity should also be offered as soon as possible to advanced students for the study of Old French, Provençal and Portuguese, and also for work in the Comparative Philology of the Romance tongues. In the Germanic field, more work of a philological character for advanced students is needed.

(R.P., 1886-91, p. 135.)

The Board immediately took favorable action and appointed Calvin Thomas to the professorship of the Germanic languages and literatures and E. L. Walter to that of the Romance languages and literatures - a position which, along with the headship of the department, he held until his death in the wreck of "La Bourgogne" on July 4, 1898.

George A. Hench, 1898-99. - George Allison Hench (Lafayette '85, Ph.D. Johns Hopkins '89), head of the Department of German, was then made acting head of the Department of Romance Languages, but this interim appointment was brought to an unfortunate end by his death in an accident in the summer of 1899. President James B. Angell thereupon assumed personal charge and directed the affairs of the department throughout the next academic year.

Arthur G. Canfield, 1900-1926. - In 1900 Arthur Graves Canfield (Williams '78, A.M. ibid. '81, Litt.D. Michigan '35) was 
appointed Professor of Romance Languages and head of the department. He retired as administrative head of the department in May, 1926, but continued his teaching until he became Emeritus Professor in 1929.

Registrar de Pont died March 1, 1906, after thirty-five years of teaching French in the department. In 1912 John Robert Effinger ('91, Ph.D. '98), who had entered the department as Instructor in 1892, was promoted to a full professorship and made Acting Dean of the Department of Literature, Science, and the Arts. He was appointed to the deanship three years later. In spite of the increase in his administrative duties Dean Effinger continued his services to the department until his death in 1933.

During Canfield's chairmanship of the department the number of courses offered was increased from thirty to well over fifty, the teaching staff was correspondingly enlarged, seminars were organized, principally for graduate students, the journal club was organized to give to members of the department and advanced students an opportunity to review and discuss in common at frequent regular intervals the results of current research, and the teachers' course was further developed. Gradually the offerings in French conversation and writing, in Romance philology, and in modern and contemporary French literature and civilization were increased.

Professor Canfield did much by precept and example - both in his teachers' course and outside it - to encourage and improve modern language teaching in the schools throughout the state. His own special fields of interest were and still are the study of the beginnings of romanticism and realism, various aspects of the study of Balzac and his works, particularly the question of chronology and the matter of reappearing characters. His published contributions on these subjects are recognized by competent scholars as distinctly significant. When on his retirement the Regents in a tribute mentioned his "quietly efficient devotion to his work and his unusual ability to co-operate with others, and a gentleness of nature which have made him a delightful colleague and well-beloved teacher," they were but voicing the feelings of his fellows both inside and outside the department, in fact of all privileged to know him.

Hugo P. Thieme, 1926-40. - At the June meeting of the 
Regents in 1926 Professor Hugo Paul Thieme (Johns Hopkins '93, Ph.D. ibid. '97) was appointed Chairman. He had come to the University as an instructor in French in 1898 and had advanced to a full professorship in 1914. In the fourteen years of his chairmanship he displayed remarkable energy and exercised his gift for organization and his talent for systematization. Under his vigorous guidance the previous development of courses was continued. In oral French and French composition the work was reorganized and new courses were introduced, the offerings in Romance philology were further expanded, and more intense and specialized instruction in modern and contemporary literature was provided. He paid particular attention to the development of the courses on the graduate level.

Professor Thieme was to have retired on June 30, 1940, but he died on June 2, after a severe illness of several months, and Hayward Keniston (Harvard '04, Ph.D. ibid. '11) was called from the University of Chicago to be Professor of Romance Languages and Chairman of the Department of Romance Languages and Literatures. Professor Thieme had been in the department for forty-two years and was a member of the council of the Société des textes français modernes and American correspondent of the Revue d'histoire littéraire de la France. For his scholarly work and for his tireless efforts in behalf of an understanding of French culture in this country, he was made Chevalier of the Legion of Honor in 1923; in 1929 he received the Prix de la langue of the French Academy; and his great bibliography was crowned, upon its publication, by the Academy.

Since the new organization was adopted in 1933, the department has been administered by a chairman and an executive committee of four appointed by the dean and executive committee of the College. This provides for greater participation on the part of the staff in matters of administration and policy.

The period of the World War. - As might be expected, the peak in the study of French was reached in 1918-19, when French 1, a four-hour course, was given at every hour from 8 A.M. to 3 P.M. inclusive, and seventeen instructors were 
employed, two of whom were women. These two, Mme Pargment and Mme Pawlowski, were designated as teaching assistants in French. That year several members of the University faculty who normally taught German - Professors Wait, Scholl, and Lee - were busy teaching beginning French. Among those teaching second-year French were Professors Bonner and Winter of the Departments of Greek and Latin. Michael S. Pargment (Dipl. d'études univ., Paris '11) gave an intermediate course in military French for enlisted men in the Students' Army Training Corps. In this course special emphasis was placed on the spoken language. Jean Petit gave an advanced course in military French, which was open to men in military training who had had more than two years of French. Emphasis was placed on spoken French for the military services. Similar courses were given in the College of Engineering. During the war, several members were on leave: Assistant Professor René Talamon (Lic.-ès-lettres [lettres], Paris '00, Lic.-ès-lettres [langues], ibid. '01), for the duration of the war in service with the French army; Herbert Alden Kenyon, then an assistant professor, in Washington with the Military Intelligence Division of the General Staff; Instructor Harry Carleton Barnett (Dartmouth '12, A.M. Michigan '17), with a hospital unit in a southern camp; Assistant Professor Philip Everette Bursley ('02, A.M. '09), in Paris at the American University Union; and Instructor Eugène Étienne Rovillain (Columbia '15, A.M. Michigan '18), in France with the French forces. As soon as the army was installed at Camp Custer, Battle Creek, Michigan, Canfield, accompanied at first by Rovillain and William Aloysius McLaughlin (Harvard '03, A.M. ibid. '20), then Assistant Professor, and later by Professor Thieme, set out once a week to give three lessons in French to the officers. This continued for months. Eventually Thieme superseded Canfield and during the summer was in uniform in complete charge of French at the camp and attached to the Y.M.C.A.

French conversation. - To make certain that students have an ample opportunity to perfect themselves in French pronunciation and to acquire facility in conversation, the staff has always included a number of teachers whose native tongue was French or who were bilingual. Notable among these have 
been Assistant Professors Paul R. B. de Pont and André Béziat de Bordes (Ph.D. Chicago '99), Jean B. Cloppet (Lic. en phil., Coll. Propaganda [Rome] '06, Doc. en phil., ibid. '08), and Louis Chapard (Dipl. d'études supérieures de droit publique, Paris '25, Dipl. d'études supérieures de droit privé, ibid. '26). This work is now under the direction of Associate Professor Talamon, assisted by other staff members, particularly by Assistant Professor Charles Emile Koëlla (Lic.-ès-lettres classiques, Lausanne '11).

Visiting professors. - In 1925-26 Professor Charles Cestre (Lic.-ès-lettres, Paris '93, Agrégé d'anglais, ibid. '95, Doc.-èslettres, ibid. '06), lecturer on American literature at the Sorbonne, gave a course called La Société française contemporaine d'après la littérature et d'après la vie. Already in 1921 he had given a course of six University lectures on the contribution of France to the universal ideal of mankind. In 1929-30 Professor Henri Chamard (Lic.-ès-lettres, Paris '88, Agrégé des lettres '90, Doc.ès-lettres, Paris '00), of the Sorbonne, offered two courses, one on French literature of the sixteenth century and the other on that of the seventeenth century. In 1922-23 an innovation was introduced by the appointment to the staff of Marcel Clavel (Lic.-ès-lettres, Paris '19, Dipl. d'études supérieures, Lille '20, Agrégé d'anglais, Paris '21), who announced a course called French Classicism in England, intended for students specializing in English or French. The following year Clavel offered in addition La Littérature française par l'explication de textes and a course on Rousseau and England. In 1929, after Clavel's return to France, Jean Edouard Ehrhard (Lic.-ès-lettres, Paris '23, Dipl. d'études supérieures, ibid. '27, Agrégé des lettres '28) was appointed Assistant Professor. He gave a course in French literature dealing with the main literary movements in France from the middle of the nineteenth century to the present day, and another, Explication de textes. Ehrhard returned to France after a few years.

Graduate studies. - Graduate courses in the field of the Romance languages have been given at the University for over eighty years. In 1858-59 the Catalogue contained a "Programme of Studies for the Degrees of A.M. and M.S.," in which a course in French literature by Fasquelle was announced for the first 
semester. For many years thereafter a similar course was offered. In the petition for the establishment of separate departments for the Germanic and the Romance languages in 1887 it was urged that the instruction in both Italian and Spanish should be continuous, and that as soon as possible advanced students

Page 721should have an opportunity to study Old French, Provençal, and Portuguese. In fact, Old French was offered for the first time in 1889, Provençal in 1900, and Portuguese in 1894. Old French and Provençal have been announced continuously since those dates, but, up to June, 1940, Portuguese was not offered again. Since 1914 the work in Provençal has been given by Edward Larrabee Adams (Harvard '00, Ph.D. ibid. '07).

Only a very general statement regarding graduate work in French appeared in the Graduate School Announcement before 1899, when the names of instructors and more detailed course descriptions were first given and the number of courses began to increase. In 1900 there was a distinct expansion in this work - an expansion which has continued until at present there are advanced courses dealing with every period of French literature from its origin to the present day, the various literary genres - criticism, drama, lyric poetry, the novel - the early history of the language, civilization, and the history of ideas. Today, requirements for advanced degrees, as well as programs of preliminary examinations according to the field of major interest, are very definitely set forth. The department has been enriched by the advent of specialists in various fields who devote much of their time and attention to initiating candidates into the problems of research, training them in methods, and critically supervising their work as it progresses. There has been a marked increase of late in the number of doctorates granted and in the number of doctoral theses in preparation in this department.

Summer session. - Courses in French have been offered in the summer session since its inception in 1894. Of late years a sufficient number of graduate students have been in attendance to warrant the offering of an increased number of graduate courses in French. In order to give summer session students an opportunity for a practical use of French, a Maison Française 
has been organized, in which board, room, and recreation facilities for a limited number of women are provided. A Cercle Français has also been organized for the benefit of summer session students, both men and women.

Societies. - In the Calendar of 1901-2 an announcement was made of a journal club in which reviews were given of current research in the field of Romance languages and literatures by the instructors in the department and advanced students. The journal club continues - though under another name, the Romance club - and now meets periodically throughout the year for the same purpose as indicated in 1901.

The Cercle Français, organized in 1902 by and for students interested in French, has effectively supplemented the oral work.

Publications. - Among the more outstanding publications by the staff, aside from editions of textbooks, are Thieme's threevolume Bibliographie de la littérature française de 1880 à 1930 (1933), Adams' Word Formation in Provençal (1913), Newton S. Bement's French Modal Syntax in the Sixteenth Century (1934), and Warner F. Patterson's Three Centuries of French Poetic Theory (1935).

- William A. McLaughlin

\section{Spanish}

Spanish was listed for the first time in the Catalogue of 1848-49. A short course was offered by Professor Louis Fasquelle in the third term of the junior year. This course must have been given as announced, for on July 16, just before Commencement, the secretary of the faculty recorded that a certain junior, Samuel Harper, was found deficient in Spanish.

There was no further mention of Spanish until the spring of 1868, when it was listed with Italian as a senior elective in all the curriculums in the Literary Department except that for mining engineering. Instruction in these two languages was offered again during parts of the next two academic years. It appears that from 1870-71 through 1886-87 Italian and Spanish were given alternately, first by Professor George S. Morris, and then, 
beginning in 1880, by Professor Edward L. Walter. A prerequisite of one year of French was established in 1881, not to be removed until 1909. In 1884 Spanish was expanded to a twosemester course. Instruction in Spanish has been continuous since 1886, except for one semester in 1888.

When the first-year Spanish work was taken over by Eugene Leser (Ph.D. Berlin '87) in 1893-94 an additional course was offered - a one-semester, one-hour course on Calderon by Professor Walter. Benjamin Parsons Bourland ('89, Ph.D. Vienna '97) had charge of the elementary courses in 1894-95. The following year he went abroad to study, and Moritz Levi ('87) taught the elementary courses. A fourth semester of Spanish, a one-hour course on Don Quixote, was introduced in 1895-96. In 1898, with the return of Bourland to take full charge of the work in Spanish, the two first-year courses became three-hour courses, and those in the second year were also increased to two hours each. It was not until 1909 that the two courses comprising the first year's work were converted into four-hour courses. A third-year course on Cervantes and the literary history of the Golden Age was added in 1900. From 1901 to 1904, when all the work in Spanish except that for the engineering students was in the hands of Winthrop Holt Chenery (Mass. Inst. Technol. '96, Ph.D. Harvard '04), there were no changes made in the courses offered.

In 1904, with the coming of Charles Philip Wagner (Yale '99, Ph.D. ibid. '02), there began a period of gradual growth and expansion that has continued to the present day. Until 1913 evidence of this interest in Spanish was to be seen in the constant increase in the number and variety of advanced courses offered; after 1913 that interest was most apparent in the addition of sections and the consequent increase in personnel. For example, in 1903 one section was sufficient to care for all beginning students, but in 1914 it was necessary to provide five sections, in 1916 twelve, and in 1919 fifteen. To care for the greater teaching load, one assistant was provided from 1909 to 1914, three were required in 1914, seven in 1916, and fifteen in 1920, when the total enrollment in Spanish classes reached a maximum of 4,339 semester hours.

As it was neither expedient nor physically possible to offer 
all of the courses every year, a system of rotation was devised that would make the more fundamental courses available every two years, and the more specialized courses every three or four years. The study of Don Quixote, which started as an irregular, one-hour, one-semester course, developed first into a two-hour course, then, in 1907, into a sequence of two two-hour courses, and in 1910 into a year course of three hours each semester offered practically every year. Spanish-American literature has been taught every year since 1925 .

Special courses for engineering students in the first two years of Spanish were conducted between 1901 and 1928. At first this work was in the Department of Literature, Science, and the Arts and was under the direction of Colman Dudley Frank ('97, A.M. '02), Instructor in French and Spanish. When the Department of Modern Languages was formed within the Department of Engineering in 1904, James Pyper Bird ('93, Ph.D. '18) was put in charge of this work. In 1915 he was succeeded by Herbert Alden Kenyon (Brown '04, A.M. ibid. '05), who continued in that capacity until, in 1928, the department was reabsorbed into the corresponding departments of the Literary College. In the peak year 1921-22 nine sections of Spanish were provided in the College of Engineering and additional instructors were engaged.

In 1939-40 the Department of Romance Languages and Literatures gave twenty-six courses in Spanish, in some of which, especially the elementary courses, there were many sections. In all, seventy-nine separate sections or classes were conducted - forty-eight elementary, twenty-seven intermediate and advanced, and four exclusively graduate.

Today a student interested in Spanish may go from his first two years of elementary work into courses devoted to literature, conversation, or composition, where he will receive special training and preparation for more advanced work. For the graduate student and the prospective teacher, various basic courses are offered in Old Spanish language and literature, philology, phonetics, pedagogy, and grammar. Outside the classroom the interest of the faculty and students has found expression in Spanish plays, radio, and in the social activities of the Sociedad Hispanica.

Charles P. Wagner was coeditor, with Louis How, of The Life of 
Lazarillo de Tormes (1917), and in 1929 the first volume of his $E l$ Libro del Cauallero Zifar appeared.

- Joseph N. Lincoln

\section{Italian}

In the autumn of 1848 the seniors in the Department of Literature, Science, and the Arts were permitted to take a oneterm course in Italian, taught by Louis Fasquelle, Professor of Modern Languages. It was recorded in the faculty minutes that sixteen seniors (exactly two-thirds of the senior class) were examined in Italian on December 20, 1848, and that all but one of them passed.

Italian was not offered again for nearly a score of years. In 1867-68 it was listed, along with Spanish, as a second-semester senior elective in five of the six programs in the Literary Department. For the next several years, although neither language was mentioned in the list of requirements and electives, a course in Italian extending through "a portion of the collegiate year" and a similar one in Spanish were announced in the brief general description of the work in modern languages. It was at least tentatively decided in 1870-71 that these two courses should be alternated, each of them to be given once in two years. In 1872 George S. Morris, then head of the Department of Modern Languages and Literature, reported that during the second semester, "with the permission of the faculty," he had taught a two-hour elective course in Italian for juniors and seniors. From the Calendar it appears likely that the plan of alternating Spanish and Italian was followed continuously, though with some irregularities, until June, 1887.

The Calendar of 1878-79 was the first in which the names of the teachers regularly appeared with the names of all courses, and also the first in which the content of the Italian course was definitely, though briefly, outlined. Cuore's Italian Grammar and Foresti's Italian Reader were the texts which Morris used. According to the definition of "full" (i.e., five-hour) courses, a fixed number of which were required for graduation under the 
regular "credit system" that went into effect the same year, the two-hour course in Italian was regarded as a "two-fifths course."

E. L. Walter took charge of the Department of Modern Languages in the winter of 1880 . He taught Italian to thirty-eight students, who, he reported, completed about half the grammar and read about twenty-five pages in the reader. In his published report to the president he urged that greater facilities in Romance languages be offered, for "no earnest student of literature can afford to be ignorant of the languages of Dante and Cervantes."

Some progress toward this goal was made when, in 1883-84, a one-year course in Italian (two hours credit each semester) was offered. In the meantime, beginning in 1881-82, a prerequisite of a year of French, or its equivalent, had been established, and I Promessi sposi had been substituted for Foresti's Italian Reader. Even more significant, however, was the introduction of a two-hour semester course in Dante, first given by Professor Walter in 1888 , only a year after he had been made head of the Department of Romance Languages and Literatures. In addition to the course devoted to the Divina Commedia, a one-hour course in the Vita Nuova was begun in 1892-93 by Raymond Leslie Weeks (Harvard '90, Ph.D. ibid. '97), Instructor in French. After Weeks left in 1893 Professor Walter took charge of the course and continued to give it and the regular Dante course until 1898, the year of his death.

From 1893 to 1923, the date of his retirement, Professor Moritz Levi, in addition to teaching French, offered courses in Italian. Others who at one time or another have been engaged in the teaching of Italian are: William A. McLaughlin, Herbert Douglas Austin (Princeton '00, Ph.D. Johns Hopkins '11), George Livingstone Hamilton (Harvard '95, Ph.D. Columbia '03), Stephen Scatori (Tulane '14, A.M. Michigan '18), Michele de Filippis (Brown '20, Ph.D. California '33), John Revell Reinhard (Harvard '15, Ph.D. ibid. '21), and Aubrey Tealdi (Lic., R. Ist. Tec. Livorno '00).

At one time or another between 1898 and 1930, Levi, McLaughlin, Hamilton, Austin, and Reinhard gave the Dante course, which had been expanded to include the Vita Nuova and a consideration of Dante's minor works, and which was 
extended over two semesters. In 1914-15 Austin introduced a graduate course of two semesters called the Origins of Italian Literature, and in 1925-26 Reinhard introduced as graduate courses the Renaissance, the Novellieri, and Petrarch.

In 1930 Camillo Pascal Merlino (Harvard '23, Ph.D. ibid. '28) was invited to take charge of all instruction in Italian. In addition to the courses available up to this time, the following new offerings, usually given in cycles, were admitted to the curriculum: Composition and Conversation; Italian Literature from 1870 to the Present Day; the Masterpieces of Italian Literature; and Introduction to Old Italian Language and Literature, including special treatment of Petrarch and Boccaccio. A Dante course in English was offered for the first time in the summer session of 1936. In 1937 Merlino accepted a position at Boston University.

The elementary Italian course, in addition to advanced work, is taught by Vincent Anthony Scanio (Buffalo '30, Ph.D. Michigan '37), who joined the department in 1931 as an instructor. There are at present three sections of this course, one of which is designed especially to meet the needs of the students of the School of Music.

There is now a complete curriculum in Italian with courses of a practical, literary, and historical nature, thus allowing for an undergraduate major as well as for a program of studies leading to the master's and doctor's degrees.

Library facilities. - In addition to a very adequate collection of Italian texts and scholarly publications on the language, literature, and history of Italy, the General Library now contains several special collections of much value. Professor Walter bequeathed to the University his own library of about 2,100 volumes, of which some 800, including nearly 500 Dante items, comprised the nucleus of the Italian collection.

The Pèrcopo collection of 1,500 volumes, the private library of the late Professor Erasmo Pèrcopo, of the University of Naples, was purchased in 1928. It includes, besides many single publications, 278 volumes containing more than four thousand research articles and monographs, many of which are very rare or otherwise inaccessible in this country. The collection is now fully catalogued. 
In 1932, Mrs. LeRoy Crummer presented to the University thirty-nine rare editions of Castiglione's Il Cortegiano. These, added to the ten already in the library, make this without a doubt one of the finest collections of its kind in the world. Probably the largest and most valuable library of Italian dialect dictionaries outside Italy is the special collection of 124 purchased in 1933.

- Camillo P. Merlino

\section{SELECTED BIBLIOGRAPHY}

Announcement, Department [College, 1915 - ] of Literature, Science, and the Arts, Univ. Mich., 1878-1940.

Calendar, Univ. Mich., 1871-1914.

Catalogue ..., Univ. Mich., 1846-71, 1914-23.

Catalogue and Register, Univ. Mich., 1923-27.

Frieze, Henry S."George Sylvester Morris."Mich. Argonaut, 5 (1886): 69-71.

General Register Issue, Univ. Mich., 1927-40.

Hinsdale, Burke A.History of the University of Michigan. Ann Arbor: Univ. Mich., 1906.

President's Report, Univ. Mich., 1871-72, 1879-80, 1899-1906.

Proceedings of the Board of Regents ..., 1864-1940. (R.P.)

MS, "Records of the Faculty ... [Department of Literature, Science, and the Arts]," Univ. Mich., 1846-57. Mich. Hist. Coll., Univ. Mich.

Shaw, Wilfred B.The University of Michigan. New York: Harcourt, Brace and Howe, 1920.

University of Michigan. Catalogue of Graduates, NonGraduates, Officers, and Members of the Faculties, 1837-1921. Ann Arbor: Univ. Mich., 1923.

University of Michigan Regents' Proceedings ..., 1837-1864. Ed. by Isaac N. Demmon. Ann Arbor: Univ. Mich., 1915. (R.P., 1837-64.)

Wenley, Robert M.The Life and Work of George Sylvester Morris. New York: Macmillan Co., 1917. 


\title{
Romance Languages and Literatures (1975)
}

\author{
James C. O'Neill
}

Since 1940, the Department of Romance Languages and Literatures has continued to offer undergraduate and graduate instruction in the languages, literatures and civilizations of France, Spain, Latin America, Italy, and Portugal, with occasional courses in such fields as Rumanian, Catalan, Francophone areas outside of France, etc. The principal additions to the departmental offerings since 1940 have been the emergence of a section for Romance Linguistics and the building up of the programs in Portuguese and in Italian.

Since 1933, the department had been directed by a chairman, advised by an Executive Committee. When Hayward Keniston became chairman in 1940 a major change in the department administration was effected: an elected Executive Committee of four members was constituted. It had two members from the French-Italian side and two from Spanish-Portuguese. One member was elected each year for a four-year term. On Keniston's appointment to the deanship of the College in 1945, 
Irving A. Leonard assumed the chairmanship. During his term of office, the administrative duties of the department were formally shared with an Associate Chairman for French: Warner Patterson held this appointment from 1945 to his death in 1948; Paul Spurlin filled the post from 1949 to 1951. When Leonard was succeeded as chairman by Charles N. Staubach, it was decided to supplement the Executive Committee by creating a Senior Advisory Council consisting of all the full professors ex officio. This Council was to advise the chair on matters concerning the appointment, retention, promotion, and salary of all members of the regular faculty. These two committees, and the Graduate Committee, were the agencies which, with the Chairman, effectively ran the department. When James C. O'Neill assumed the direction of the department (as Acting Chairman 1959-60, Chairman 1960-73) he urged his colleagues to consider merging the Executive Committee and the Senior Advisory Council into one effective committee to advise the chair, but they preferred to retain the operating arrangement, and it was continued. When O'Neill resigned the chairmanship in 1973, Frank Casa was appointed chairman.

The department offers instruction at all levels in the French, Italian, Portuguese, Provencal, and Spanish languages and literatures, and in Romance Linguistics. This was already an extensive enterprise in 1940, and its dimensions have increased impressively since then. In 1940, the department had a regular staff of 33 faculty members who taught a total of 205 separate classes during the academic year (Summer Session programs are not included in statistics here or later). In 1975, there were again 33 full-time members in an instructional staff which was teaching 429 separate classes. These years - 1940-1975 witnessed the invention and then the enormous expansion of a new teaching rank, the Teaching Fellow or part-time graduate assistant. In 1940, there were no classes taught by Teaching Fellows. In 1975, 266 classes were in their charge.

In 1940, the department was still quartered in the Romance Languages Building where it had been since 1928. The first language laboratory, however, was in the South Wing of University Hall. New quarters were allotted to the department in 1959 in the newly-acquired Frieze Building. A language 
laboratory founded by the department and made available to other language departments had been moved to Mason Hall. In 1971, the present Modern Languages Building was at last completed and the department moved to its present quarters on the fourth floor.

Undergraduate enrollments in the department are largely a function of the foreign-language requirement for various degrees in the College, and of the recommendations for language competence made by the several preprofessional programs. Since the College has maintained a basic requirement of fourth-semester foreign-language competence or the equivalent for the B.A. degree, a large commitment to elementary and secondary language instruction continues to be one of the major responsibilities of the department.

With the beginning of the war, special language training courses were designed in all sections of the department for students who were soon to enter military service. From 1941 to 1945 such courses were offered in the regular year in French, Spanish, and Italian. Faculty members also lectured on foreign civilizations and gave language training courses in military installations away from Ann Arbor. Then in the summer of 1942 the department furnished staff for both language and area studies in the Civil Affairs Specialist Training Program (CATP) and subsequently also for the Army Specialist Training Program (ASTP) in languages. After the end of hostilities, a special program was set up in the University for the training of field officers from the various military services for possible postwar assignments in Latin America. It had two parts, one an interdisciplinary course in the culture and society of LatinAmerica, the other an intensive language program in Portuguese and Spanish.

A project worthy of special mention is the department's part in the Foreign Language in the Elementary School program (FLES). When the national enthusiasm for FLES began to emerge, the department organized special FLES training programs in the summer sessions, in which teachers from elementary schools learned the techniques of teaching French or Spanish to students at that level. These programs began in the summer of 1956 and continued for many years with nationally 
recognized success. The department was also a major participant in one of the pioneer Institutes supported by the National Defense Education Act (NDEA). The Institute at Michigan in the summer of 1959 was one of four held in the nation, the forerunners of many NDEA language institutes to come in the years to follow. It offered special remedial training in French, Spanish, Russian and German to a group of 100 high school language teachers and superintendents chosen in a nation-wide selection.

The department has also been a major supporter of and contributor to several collegiate programs of note. It was represented on the college committee which first devised the Great Books courses for freshmen in 1945, and faculty members from Romance Languages have consistently figured among the teachers in these courses. The departmental faculty has also played an important role in the program in Comparative Literature, with staff members serving on the directing committee and faculty of the program, as well as filling the posts of Director or Associate Director at various times. When the Residential College was created in 1967, members of the department were instrumental in the early planning of the curriculum, particularly in connection with a novel scheme for integrating foreign language into the programs. The department has supplied the necessary junior teaching staff in French, Spanish, and Italian, and its professors frequently offer courses and seminars in the core curriculum. 


\section{Romance Languages and Literatures (2013)}

\section{Steven N. Dworkin}

\section{French}

By 1940, the regular French staff numbered 16 instructors who offered a total of 118 classes during the academic year. After that time, the number of full-time teachers did not vary greatly, as the increasing need for instruction was in large part being met at the level of basic and intermediate language teaching by teaching fellows. The peak of student enrollment in French came in 1965, when 305 classes were taught.

In that era, the French section offered instruction in the use of French at all levels, in the methods of teaching French, in French civilization and history, and in French literature of all periods. The methods used followed the development of new approaches in applied linguistics and pedagogy, but the objectives remained the same.

From the early years of this century, training in the active use of correct French had been provided both incourses and through extracurricular activities. The most significant recent 
addition to the undergraduate program in French were the opportunities for supervised study abroad. In 1962 a Junior Year Abroad, run jointly by the Universities of Michigan and Wisconsin, was set up at Aix-en-Provence. Every year, twenty-five students from each university spent an entire academic year enrolled in the Universite de Provence, earning a full academic year's credit in their home university. The two universities alternated in providing a French faculty member to be the resident director. In the summer of 1974, a program of intensive study of French at the elementary and intermediate levels was established at La Rochelle. Under the direction of French staff from the Department, students could do a semester's or a year's work for regular university credit. Some were able to complete the LSA foreign-language requirement during this intensive seven-week session. The site of the summer French program in France subsequently changed several times over the years to Tours, St.-Malo, and Grenoble.

The overall picture of graduate studies in French from 1940-1975 is rather different from that of the undergraduate experience. In the 1930s, the Department had made an active effort to develop a graduate program equal to that of other major universities, and the French section profited from it immediately. The French section also offered three special graduate programs. Between 1952 and 1956, a special sixweek program for teachers of high-school French and Spanish was organized under the direction of Benjamin Bart, then supervisor of basic instruction in French. Under the National Defense Education Act, a series of institutes was organized and directed by U-M's Jean Carduner. Four of these NDEA French Institutes were offered, the first two in Ann Arbor in 1966 and 1967, the second two in France, at Sevres and Cahors in 1968 and 1969. These institutes were created for a particular clientele-teachers of advanced high school courses in French literature and civilization, or supervisors of such programs. Some 150 students took advantage of this opportunity to upgrade their professional skills.

Between 1848 and 1940, the Department had awarded 110 master's degrees in French and 14 Ph.D.s in Romance 
Languages and Literatures, with French as the major field. Between 1940 and 1975, 341 master's degrees in French and 84 Ph.D.s in "Romance Languages and Literatures: French" were granted.

\section{Italian}

Camillo P. Merlino had been the only regular professor of Italian from his appointment in 1930 to his resignation in 1937. After his departure, Vincent A. Scanio was for many years the only full-time faculty member of the Italian section. In 1940, ten classes were offered. During the war years, special classes in Italian were provided to various military and civilian programs, and a Conversational Grammar by Scanio and William Aloysius McLaughlin was widely used, and received official commendation from the government. As enrollments increased, they were accommodated by the employment of teaching fellows and by bringing a series of visiting lecturers from Italy to supplement the staff for the upper-class offerings.

By 1970, there were 40 classes taught in Italian. The development of the Romance linguistics section of the Department included the offering of various courses in preItalic and Old Italian language, taught by Ernst Pulgram, and these courses were available to graduate students in Italian. From 1940 to 1975, five master's degrees and one Ph.D. were granted in Italian.

\section{Romance Linguistics}

Before 1948, a few courses in philology were offered in the Department. All of them were ancillary to literary studies, although some courses were required of students in the various languages. Their principal purpose was to provide students with a knowledge of the medieval languages-French, Italian, Provençal or Spanish-so that they could read the literatures of the early periods. In 1949, the Department instituted its first courses in the field of Romance linguistics and established a graduate degree program separate from those in literature. From 1950 to 1975, 58 master's degrees and 34 Ph.D.s in Romance linguistics were awarded. 
Romance linguistics' involvement in elementary language instruction also bore fruit. During World War II, linguists had established a language teaching program for the benefit of civilian administrators, Army and Navy personnel, and prospective members of the occupation forces. It was based on linguistic principles (later called applied linguistics) and aimed at a practical oral-aural mastery of the language apart from any literary or aesthetic purposes. Under the auspices of the Department, a language laboratory was established, and elementary instruction began to show the influence of the postwar trends in language teaching. The existence of a program in Romance linguistics led eventually to the establishment of an autonomous Romance linguistics section within the Department.

\section{Spanish}

The Spanish section of the Department in 1940 included three tenured faculty members and offered a total of 78 classes during the academic year 1940-41. In addition to the normal basic language instruction, the upper-class and graduate program included a rotation of courses in Cervantes; the theater of the seventeenth, nineteenth and twentieth centuries; and the novel of the medieval and Golden Age periods and of the nineteenth and twentieth centuries. There was one course in LatinAmerican literature and one in grammar for future teachers.

Staff and course programs remained substantially unchanged during the war years. Following the war, in 1945, 121 classes were being taught, including nine intermediate literature courses, three teacher preparation courses, and eleven graduate courses. A year later, instruction in Portuguese was reintroduced, with basic language courses and two semesters of Portuguese and Brazilian literature. This expansion reflects the increased American interest in Spanish-speaking countries and the development of high school language programs, which is evident in the statistics: by 1960, the section was offering 143 classes in the academic year, of which 26 were at the advanced undergraduate level and 17 were graduate courses.

The 1960s was a period of intense activity, both in teaching 
and in scholarship, as the Spanish section sought to handle the problems created by a swollen student population. Beginning in 1974, the undergraduate offering was broadened by a sevenweek intensive summer program at Salamanca, for elementary and intermediate language study. The Department would next expand its opportunities for summer study in Spanish-speaking countries.

\section{$1975-2013$}

The Department has undergone many changes over the last forty years regarding its faculty composition, administrative structure, curriculum, and the intellectual focus of its faculty and graduate students. With the exceptions of Steven Dworkin, who joined the Department in 1979, and Alina Clej and William Paulson, who came in 1986, all tenure-track faculty serving in 2013 had been hired since 1991. Frank Paul Casa, who became chair in 1973, continued in that role until 1983. His successors have been Jean Carduner (1983-87); Thomas Kavanagh (1987-1992); Noël Valis (acting, 1989-90); William Paulson (1992-1997, with Roy J. Nelson serving as acting chair in 1992-93); José Rabasa (1997-98); Steven Dworkin (1998-2003, with William Paulson serving as acting chair in the winter term of 2000); Peggy MacCracken (the first woman to serve in this role, 2003-2006); Michèle Hannoosh (2006-2010, with Cristina Moreiras-Menor serving as interim Chair in 2008-09); and Cristina Moreiras-Menor (2010-).

Until the late 1980s, the Department maintained its longstanding administrative/governance structure. The unit was headed by a chair who worked with an elected sevenmember Executive Committee that included at least one member from each of the four "sections" offering degree programs-Spanish, French, Italian, and Romance Linguistics. Each section had its own nominal head, graduate committee, and undergraduate committee, and had a degree of autonomy. By 1978, the Department had eliminated the Senior Advisory Committee, which had been created in 1960-61 and was comprised of all of the Department's full professors. There would be some resentment when members of one section 
opposed requests made by another section, or when the chair and/or the Executive Committee made decisions contrary to the perceived interests and desires of the majority of the faculty in the individual sections.

This situation led LSA Dean Peter O. Steiner to remark that the Department was in reality four separate departments under one chair and with one budget. There was little intellectual unity; there were few joint ventures or classes that crossed the boundaries of the individual languages. Students studied Spanish, French, or Italian literature; they did not study Romance literatures and cultures in a holistic fashion. The sole exception was the graduate program in Romance linguistics, which required its students to study the history and structure of at least three Romance languages.

Rivalries and resentments among the sections (and individual faculty) led to a serious crisis in the mid-1980s. Several members of the Department (especially from the Spanish section) advocated for the division of the Department into two separate units, while others argued for remaining unified. The situation reached a crisis in late 1985 when Dean Steiner declared that the Department was ungovernable in its current form; he said it would be preferable to divide the Department into separate Spanish-Portuguese and French-Italian units. He declared a willingness to allow the Department to stay together if it was able to change its internal organization and operations. The Department formed an advisory committee on departmental reorganization; it recommended that the dean authorize a search for an outside chair who would heal the rifts and provide the Department with a new direction as a cohesive academic unit. The Dean agreed and gave the Department two years to conduct a successful search. If the search failed, the Department would be divided into the two smaller units.

The search led to the hiring of Thomas Kavanagh, then professor of French at the University of Colorado and already a distinguished scholar in the field of French eighteenth-century literature. Kavanagh became chair at the start of the 1987-88 academic year. Among his first acts was the drafting of new Statutes of Organization for the Department. In an effort to have the Department function as a single administrative unit, 
the notion of representation by sections on the Executive Committee was eliminated. Instead, the Executive Committee was to consist of five elected faculty members, at least three from the tenured ranks and at least one from the ranks of assistant professor or lecturer. The Statutes recognized the existence of four Teaching and Research Groups (TARGs)-Spanish, French, Italian, and Romance Linguistics-which could organize as each saw fit to carry out their respective functions. The Statutes specified that no TARG "shall have independent authority in matters affecting the budget of the Department." Each TARG could have its own graduate and undergraduate committees and propose curricular changes and degree requirements. However, such changes were subject to the approval of the chair and the Executive Committee. The TARGs were also required to have non-voting student representatives on their committees. Starting in 1993, under the leadership of William Paulson, two non-voting student members began to serve on the Executive Committee.

This administrative structure remained in place during Kavanagh's period as chair, which ended in 1992. As a result of an external review undertaken in the winter term of 1995 , the Department created the position of associate chair. The associate chair has become responsible for the undergraduate curricula. With the restructuring of the Department's graduate programs in 1996, a single departmental Graduate Committee, with a chair, also was formed.

Until 2001, the Executive Committee determined whether a case for promotion would be forwarded to the College for its decision. After the LSA Executive Committee reformed promotion procedures across the College, all of the Department's promotion recommendations were to be decided by a vote of those faculty members ranked higher than the promotion candidate. This administrative and governance structure remains in place.

Until the sudden increase in Spanish language instruction in the U.S. during the $1960 \mathrm{~s}$, the largest enrollments of undergraduate majors and graduate students in the Department were in French. In 1981, there were 69 concentrators/majors in 
the Department. By 1989, Spanish alone had 69 concentrators, and by the end of the 1990s the total number of concentrators/ majors had risen by more than 115 percent. In the academic year 1994-95, the number of Spanish concentrators began to surpass the number of French concentrators.

In the late 1990s, the College introduced academic minors, with the proviso that a student could not major and minor in the same Department (which adversely affected students in Romance languages who may have wished to major in one language and minor in another). The Spanish and French minors began in 1999, followed by the Italian minor in 2003. A Portuguese minor started admitting students in 2013; there is still no Portuguese major. Since 2000, the numbers of students majoring or minoring in Spanish has increased considerably. In the winter term of 2011, there were 511 declared Spanish majors. Many students took Spanish as part of a double major, with the hope that a degree in Spanish would make them more attractive on the U.S. job market. The increase in minors was so great that the Department was unable to staff sufficient courses to meet the demand and had to temporarily suspend new admissions to the minor in 2006-07.

After negotiations with the College regarding extra faculty positions in Spanish to meet student demand for upper-division classes, the Department reinstated a revised minor in Spanish with more stringent course requirements. It was hoped that these new requirements would persuade students to opt for the Spanish major rather than the minor, which is in fact what happened. In the winter term of 2013, there were 161 students pursuing a minor in Spanish while the number of students majoring in French and Francophone Studies has fallen off considerably. In the period 2000-2013, the number of French and Francophone Studies majors has ranged from a low of 49 to a high of 86, while minors in French and Francophone Studies went from a low of 15 to a high of 76 . In the same period, the number of Italian majors has ranged from a low of 6 to a high of 19. An Italian minor was introduced in the fall semester of 2003.

The curriculum of the Department's undergraduate and graduate programs has changed over the years. At the undergraduate level, less emphasis has been placed on the study 
of the traditional periods, genres, and canonical works of the national literatures, with greater stress placed instead on courses dealing with wider themes and with broader cultural studies, especially film and other non-literary media, as creative means of expression and cultural vehicles. The Spanish program has also offered its undergraduate students a variety of courses dealing with Spanish linguistics, whereas French and Italian have shown less interest in this branch of study, despite some student interest. One perennially popular linguistics course in French phonetics has been continued despite the retirement of Hélène Neu, the French faculty member with formal training in linguistics. There has been a notable increase in preprofessional language courses such as Spanish for Business, French for Business, and Spanish for the Health Professions, all of which attract large numbers of students.

In order to give students the opportunity to study the language, literature, and culture of more than one Romance language, the Department created in 2008 a Romance Studies major. Whereas the individual language majors require 30 hours of upper level course work, this major requires 42 hours. At the time of publication, it was still too early to know whether the College's decision to allow students to take a major and a minor in the same department would affect enrollment in the Romance Studies major.

Since the mid-1990s the graduate programs in the Department have undergone major changes. The Department decided not to admit students whose stated goal was a terminal master's degree in one of its programs. Over time, the old system of required courses in the various fields of literature and the traditional written qualifying exams for candidacy to the Ph.D. were abolished and replaced by an oral evaluation of the student's academic portfolio carried out by individual committees formed for each student. The students, in consultation with their respective committees, decided which courses they would take. Interdisciplinarity was encouraged, with students taking graduate courses in other academic units. Students were no longer expected to have a broad overview of the ever-expanding fields of literary and cultural studies. The Department, working in concert with the College and the 
Rackham School of Graduate Studies, radically restructured the means by which graduate students were economically supported. First-year graduate students were given fellowships and did not teach in the first year. The number of students who could be admitted was limited to the number of graduate students for whom there was first-year fellowship support. In the next three years of their studies, graduate student instructors taught one course per semester, continuing the trend to reduce teaching loads for graduate students, who had normally taught four courses per year in the Department until 1988, and three per year from 1988 to 1998. As a consequence, the size of the entering graduate student cohort each year was drastically reduced, and the number of graduate courses offered each year fell sharply. Beginning in 1988 and even more so after 1998, a large cohort of lecturers was employed to teach elementary and intermediate language courses. Although the number of students has declined, the Spanish and French graduate programs have flourished during the period 1980 to the present, Spanish being the more successful.

Italian has had its ups and downs. Through the 1983-84 academic year, the Department had three full-time tenure-track or tenured faculty in Italian. Between 1984 and 1986 the number dropped to two. After 1986, with the retirement of Oscar Budel, Italian had only one full-time faculty member, Ilene Olken, and the Italian graduate program was suspended. In 1988, Gregory Lucente arrived to assume a half-time appointment as professor of Italian; by then Olken was working half-time due to serious health concerns. In 1992 Nelson Moe was hired as an assistant professor; but he remained with the Department only two years, at which point Olken retired, leaving the Department with only one half-time appointment in Italian. During this entire period, prospective graduate applicants in Italian were referred to the program in Comparative Literature, where they often worked successfully under the direction of Gregory Lucente. In 1995, Alison Cornish joined the faculty as assistant professor, bringing the faculty numbers up again. Lucente's untimely death in the summer of 1997, however, left the Italian section with only one faculty member. In 1998 the Department hired Vincenzo Binetti full-time and Paolo Squatriti in a partial appointment; these 
hires, combined with new funding opportunities for students, led to the reestablishment of the Italian graduate program in the fall term of 2001.

A number of the Department's graduate students have gone on to distinguished careers as teachers and research scholars at major universities - in French, Larry Kritzman, Lynne Huffer, Melanie Hawthorne, Alan Pasco, Mireille Rosello; in Spanish, Ivy Corfis, Susana Draper, Noel Fallows, Frank Dominguez, Anthony Pasquariello, Ruth Hill, Patty Keller, Luis Martín Cabrera, Noelia Cirnigliaro, Sebastián Díaz, Alejandro Quin; and in Romance Linguistics, Jurgen Klausenburger and Joel Rini. Many graduates hold tenured positions at leading research universities, including Yale, Princeton, Cornell, Dartmouth, Vanderbilt, University of Georgia, University of Utah, University of Illinois, Northwestern, University of Virginia, University of Wisconsin, University of California-Berkeley, University of California-San Diego.

As noted above, in 1948 Ernst Pulgram and Lawrence Kiddle established a graduate program in Romance Linguistics which had on its faculty a number of distinguished scholars, and which attracted a respectable number of graduate students. By 1980 the program's faculty included Steven Dworkin, Clifford S. Leonard, Raleigh Morgan, Ernst Pulgram, Michio (Peter) Hagiwara, and David Wolfe. But a combination of factors-the retirements of Pulgram and Morgan in 1985 and 1986, animosity between Dean Steiner and Pulgram, and the antipathy of many Department faculty toward the program-led to a severe reduction in its scope, and the Department was never authorized to replace Pulgram, Morgan, Leonard, Hagiwara, and Wolfe. By 2013, the Spanish program had three tenuretrack faculty (Dworkin, Satterfield, Henriksen) who continued to offer courses in various areas of Spanish linguistics. There was still a joint graduate degree program in Linguistics and Romance linguistics, but there were no students following this degree track. From the time of its founding until about 2000, the Romance Linguistics program awarded some 50 doctorates and more than 50 master's degrees.

There is a symbiotic relationship between the academic changes instituted in the Department's degree programs over 
the years and the scholarly profiles of the unit's professorial faculty. The large number of students majoring or minoring in Spanish has led to a steady growth in the number of tenuretrack faculty. Once the step-child of Spanish studies at Michigan, Latin American literature and culture (which includes U.S. Latinos and Latinas) has steadily increased in its role and profile, with the majority of faculty and graduate students working in these areas. Hiring of new faculty in French has stressed non-traditional areas such as French-speaking North Africa and Canada, Francophone gay literature, and the interface between literature and art. Since the mid-1990s, with a growing emphasis on interdisciplinarity and the crossing of traditional academic boundaries, a significant number of the Department's faculty have shifted their appointments to other academic units. In recent years, Department faculty have held budgeted positions in such units as Comparative Literature, American Culture, Linguistics, Screen Arts and Cultures, History, and Women's Studies.

As the University has stressed international academic experiences, so has the Department increased opportunities for students to take courses for degrees while studying abroad for an entire academic year or semester. The Department also sponsors summer programs in Spain, France, and Italy. In 1962, U-M in collaboration with the University of Wisconsin established a year-abroad program in Aix-en-Provence, France, and in the 1970s, a junior year abroad program was established in Fiesole near Florence in a villa rented by the participating universities. In 1985, a junior year abroad program was established in Seville in collaboration with Cornell University; and in 1995 the University of Pennsylvania joined this program, which has continued to flourish. Although the programs in Aix and Florence no longer exist, new academic year and summer programs have been created in such sites as Grenoble, Paris, Senegal, Ferrara, Perugia, Madrid, Granada, and Santiago de Compostela. Students may also take courses and receive University credit toward degrees in Romance Languages and Literatures at numerous other foreign universities.

The Department of Romance Languages and Literatures is considered one of the best in the country, with many prominent 
scholars of French, Italian, and Spanish such as Ross Chambers, Michel Pierssens, Walter Mignolo, Rolena Adorno, Noël Valis, José Rabasa, Mireille Rosello, and Domna Stanton.

Every semester, the Department admits a large number of students interested in language as well as those wishing to specialize in the study of one or more Romance literatures. Undergraduate enrollments in the Department are largely a function of the foreign-language requirement for various degrees in the College, and of the recommendations for language competence made by the several pre-professional programs. Since the College has maintained a basic requirement of fourth-semester foreign language competence or the equivalent for the B.A. degree, a marked commitment to elementary and intermediate language instruction continues to be one of the major responsibilities of the Department. The Department maintains between sixty and seventy language instructors, and its graduate program has an outstanding record of placement for its students. Members of the faculty are internationally recognized for their interdisciplinary research, and they attract students from around the world. In 2013 the Department had twenty-eight tenured professors and five assistant professors who taught regularly in the majors and minors as well as in the Graduate Program.

The first section of this history is a condensation and revision of the article that appeared in The University of Michigan: An Encyclopedic Survey (1940). The second section is based on an unpublished history written ca. 1975 by Monroe Z. Hafter (who served in the Department from 1960-1996). The final section was written in the fall semester of 2013 by Steven N. Dworkin, the longest-serving member (1979-) of the Department at that time. 